\title{
An Intersectional Feminist Perspective on LGBTQ Youth in Foster Care: Implications for Service Providers
}

\author{
Amy E. Nourie ${ }^{1, *} \&$ Victor W. Harris ${ }^{1}$ \\ ${ }^{1}$ Department of Family, Youth and Community Sciences, University of Florida, Gainesville, USA \\ *Correspondence: 1669 Ludington Ave., Wesley Chapel, FL 33543, USA. Tel: 1-352-857-9697. E-mail: \\ Amynourie@ufl.edu
}

Received: June 24, 2018

Accepted: August 21, 2018 Online Published: August 24, 2018

doi:10.5430/wje.v8n4p177

URL: https://doi.org/10.5430/wje.v8n4p177

\begin{abstract}
LGBTQ children are overrepresented in the foster care system in the United States. These children are also at higher risk for homelessness and suicide. While there are some legal protections for this population, more research and advocacy are needed to help these young people thrive despite their situations. An intersectional feminist perspective on advocacy and queer theory could change the landscape of political activism and training for child welfare professionals. In this article, three activist approaches to training are discussed as ways to revolutionize advocacy and treatment of LGBTQ youth in child welfare. The authors propose 1) providing intersectional and feminist principles in child welfare diversity training modules, 2) including the exploration of self-identity in these trainings, and 3) developing a better understanding of how heteronormative bias and perceptions of deviance can be perpetuated.
\end{abstract}

Keywords: foster care, LGBTQ, intersectional, feminist theory, queer theory

The Florida Department of Children and Families (DCF) removes over 1,000 children each year from their biological parents or caregivers due to substantiated allegations of abuse, abandonment or neglect. Their website states that, as of November 2017, there were 24,145 children in out-of-home care in Florida. Thousands more children and families receive diversion or other services while remaining in the home of the parents (Florida Department of Children and Families, 2018). The Human Rights Campaign estimates that approximately 400,000 children are living in foster care nationally (Human Rights Campaign, 2018).

The Children's Bureau, an office of the Administration for Children and Families, an agency within the United States Department of Health and Human Services, creates an annual report of child welfare statistics known as The Adoption and Foster Care Analysis and Reporting System (AFCARS). This annual report estimates how many children are in foster care in the United States for a given fiscal year, as well as the ages, sex and ethnicity of these children, the reason they are in foster care, their case plan goal, length of time in foster care, and their most recent placement. Most children are removed from their parents due to neglect and/or substance abuse by the parents. However, many children are also placed into foster care due to child behavior problems, drug and alcohol abuse, abandonment and relinquishment (U.S. Department of Health and Human Services, Administration for Children and Families, Administration on Children, Youth and Families, Children's Bureau, AFCARS, 2016). Some of these parents voluntarily allow children to be placed into foster care because they cannot handle their behaviors. These rejected children are often disproportionately LGBTQ (Lambda Legal, 2015).

A 2016 updated poll by the Williams Institute estimated that $4.1 \%$ of the population in the United States identify as LGBTQ (Williams Institute, 2016). For the purposes of this article, LGBTQ includes individuals that identify as lesbian, gay, bisexual, transgender and/or queer or questioning, and also includes those that identify as intersex, asexual and pansexual, among many other non-mainstream sexual orientations or gender identities. GLAAD, previously the acronym stood for the Gay and Lesbian Alliance Against Defamation, developed a survey in 2016 that suggested that up to $12 \%$ of the Millennial population in the United States consider themselves something other than cisgender, or a person whose gender corresponds with their sex assigned at birth. Most other studies and surveys believe that approximately $3 \%$ to $4 \%$ of the US population is not heterosexual (GLAAD, 2017).

For decades feminists have used feminist theory to describe gender inequality around the world. Feminist theory has 
evolved over time to become more inclusive of different cultures, ethnicities and gender identities. Though the term intersectionality wasn't used in academia until approximately thirty years ago, the concept of including marginalized women into mainstream feminism has always been a struggle and in need of ongoing discussion. Intersectionality and feminist theory allows researchers and practitioners to treat people holistically and to understand the many forms of discrimination that a person can experience.

Child welfare professionals have indicated that LGBTQ youth are overrepresented in foster care. One study in Los Angeles, California, for example, reported that as many as $19 \%$ of children in child welfare could identify as LGBTQ (Martin, Down \& Erney, 2016). This disparity and overrepresentation of LGBTQ youth in foster care is alarming and warrants the question, "What is being done for these children?" The purpose of this article is to use both research and theory to integrate a review of the American foster care system, an intersectional feminist perspective, and queer theory into suggestions for a diversity training approach for child welfare professionals who can then use this training in the prevention and treatment of high-risk behaviors for LGBTQ children.

\section{Literature Review}

Historically, public and private institutions have assumed the care for children with no parents or if parents are not able to care for their children. Orphanages and other charities were tasked to provide the necessities for these children, though they were not viewed as parental substitutes. According to the Children's Bureau, in their 2012 e-book, The Children's Bureau Legacy, Ensuring the Right to Childhood, Charles Loring Brace established the Children's Aid Society in 1853 and helped place urban orphans in the homes of rural families throughout the Northeast. Brace, an abolitionist and Darwinist, felt placing children on "Orphan Trains" and sending them to the countryside would allow these children the possibility of having better lives. The Children's Aid Society and Brace's protection of vulnerable children were precursors to the establishment of the Children's Bureau by President Taft in 1912. It was not until 1958, however, that amendments to the Social Security Act mandated local and federal government funding and oversight to child welfare agencies (U.S. Department of Health and Human Services, 2012).

Millions of children in the United States live with someone other than a biological parent. Most of these children are "informally" placed with relatives and receive no extra financial assistance (Lee, Lee, Kramer \& Choi, 2017). Some of these children have been removed from their homes by an organization such as DCF and have been placed with relatives or non-relatives to provide for their safety. Overall, placement with family, or a non-relative who may be seen as family, is usually considered the best placement option for a child if the biological parents are unable to care for them. If there are no other options, a child will enter into foster care. Though group homes and other residential programs are still considered foster care, many children are placed into individual foster homes because they can typically provide a more "family-like" setting and atmosphere (Goemans, van Geel \& Vedder, 2015).

Most children enter into foster care due to abuse, abandonment, or neglect by one or both of the biological parents. Maltreatment of children can range from physical and sexual abuse to more common forms of neglect such as inadequate supervision and educational, medical or nutritional neglect (Forkey \& Szilagyi, 2014). According to Forkey and Szilagyi, approximately 30\% of children entering foster care are "teens placed by the courts because of their own behaviors or because parents are seeking mental health services, cannot manage their behaviors, or abandon them" (2014, p. 1060). Although child welfare strategies have recently changed in order to achieve permanency for children in a timelier fashion, some children remain in foster care for significant periods of time. Children with "unique needs" often stay in foster care longer. These unique needs might include "the intellectually disabled, the severely mentally ill, pregnant or parenting teens, unaccompanied refugee minors, and those abandoned by their families because of the child's mental health or behavioral issues, or because they are gay, lesbian, bisexual, or transgender" (Forkey \& Szilagyi, 2014, p. 1060). Many children that remain in foster care for longer periods of time are teenagers who are a higher risk population for several poor outcomes, including dropping out of school, teen pregnancy, and running away from their placement.

Running away from their placement is an especially risky behavior for older foster children. There have been many studies concerning the risk factors and predictors of running away from foster care, although it wasn't until recently that LGBTQ children were specifically mentioned as having this and additional risk factors. Teenagers often run away from home. While the numbers vary, most agree that more than one million children run away from home each year. Children in foster care are twice as likely to run away (Crosland, Joseph, Slattery, Hodges \& Dunlap, 2018). Several studies also note that youth of color are more likely to run away from a foster home, although these youth numbers are somewhat skewed because youth of color are also overrepresented in the child welfare system. Children, especially teenagers who run away from foster care, may become involved in crime and substance abuse, have a higher incidence 
of homelessness, and are more likely to become human trafficking victims. African American children in the child welfare system are at an even higher risk for entering the juvenile justice system (Sarri, Stoffrengen \& Ryan, 2016). Running away from foster care has also been associated with difficulties in adulthood including experiencing depression and homelessness (Courtney \& Zinn, 2009).

Almost all children who are placed in foster care have experienced varying degrees of trauma. Removal from a parent is, itself, a trauma, but most of these children have already experienced multiple traumas by the time they enter foster care. Often, especially for teenagers, these traumatic events continue throughout their foster care experience. Exposure to long-term "toxic stress" causes physiological changes in the body and children are not usually equipped to respond appropriately. Children placed in foster care frequently already have physical and mental health issues due to their exposure to trauma and maltreatment and most are also undereducated (Forkey \& Szilagyi, 2014). Children, especially teenagers placed in foster care, have often already been labeled as having behavioral problems, such as substance abuse and mental health issues. Long-term stress, traumatic experiences, and the likelihood of ongoing abuse or neglect often get ignored due to the focus on their immediate destructive behaviors (Sarri, Stoffrengen \& Ryan, 2016).

LGBTQ youth are significantly overrepresented in foster care and in the homeless youth population. Maccio and Ferguson (2016) predicted that between $20-40 \%$ of runaway and homeless youth identify as LGBTQ. Most of these children have run away or were kicked out of their home by their parents, including by both biological and foster parents (Maccio \& Ferguson, 2016). The most cited reason for homelessness among LGBTQ youth is rejection after "disclosing" to their family (Castellanos, 2016). However, in a study conducted with LGBT Latino homeless youth in New York City, most stated that their LGBT identity was only part of the reason for their homelessness and that "disclosure of sexual orientation exacerbated preexisting family conflict," which led to the youth running away or being kicked out of the home (Castellanos, 2016, p. 605-606). Just like children in foster care, the LGBTQ homeless youth population often encounters multiple and different traumatizing events throughout their young lives.

In 2011, the Children's Bureau issued a memorandum concerning LGBTQ youth in foster care. The memo stated that LGBTQ youth are entitled placement in safe and affirming foster homes. Also, child welfare workers should be adequately trained in the specialized needs of these youth and recruit foster and adoptive homes that are affirming and committed to these children (U.S. Department of Health and Human Services, 2011). Despite this federal memorandum, research still evidences that LGBTQ children are overrepresented in the child welfare system and that they are less likely to achieve permanency when compared to non-LGBTQ youth (Hatch, Burwick, Gates, Baumgartner \& Friend, 2014).

Studies have also shown that LGBTQ youth are more likely to be "dually involved" in the child welfare system as well as in the juvenile justice system (Irvine \& Canfield, 2016). Several surveys of youth involved in the juvenile justice system noted that only $11 \%$ of straight youth were previously removed from their homes while $30 \%$ of children who identified as lesbian, gay, bisexual or questioning were previously removed. Teens who identified as gender non-conforming or transgender were even more likely to have been involved in the child welfare system (Irvine \& Canfield, 2016). These studies have also suggested that LGBTQ youth involved in the juvenile justice system were also more likely to have experienced physical abuse and run-away episodes prior to being involved in the child welfare and the juvenile justice systems (Irvine \& Canfield, 2016, p. 247).

Studies have also suggested that LGBTQ individuals, especially youth, are more likely to have a long list of psychological symptoms including depression, anxiety, low self-esteem, and they are also at a higher risk for suicide. The stigma and rejection a child experiences related to their LGBTQ identity often predicts long-term mental health issues as an adult. LGBTQ teens are also more likely to experience bullying and are more likely to ruminate, be hyper-vigilant, and lonely, which can lead to increased stress and mental health issues (Hatzenbuehler \& Pachankis, 2016).

\section{Theoretical Perspective}

\subsection{Feminist Theory}

There has never really been one definition of feminism or feminist theory since its inception. However, the most well-known form of feminist theory states that our society is based on a patriarchy that favors white, heterosexual men (Dunn, Clark \& Pearlman, 2017). Among other things, the second wave of feminism encouraged women to fight the patriarchy to obtain equality in the workforce, to fight for reproductive and equal voting rights, and to seek access to affordable childcare. This second wave also encouraged a national discussion about sexual violence. Nevertheless, at a time when black activists were also seeking equal rights, the second wave of feminism espoused a sameness among all 
women that prompted color blindness. The white women leading this movement failed to acknowledge the different experiences of women based on their race, ethnicity, and class. Focusing on the fact that all women are the same is a form of white privilege that ostracized women of color. The second wave of feminists felt that women were oppressed only because they were women, but they failed to note that women of color may experience the same event or sexism and understand it in a different way due to their many contextual "identities." Many scholars believe that black feminism was born around the same time as white feminism through the civil rights movement, although it was not developed as a backlash against white feminism (Clawson, 2008).

Third wave feminism rejected the notion that all women are unified in a sisterhood. This new wave discussed women of color, postfeminism, anti-colonialism, essentialism, and differential consciousness. Women were not viewed as all the same - they were not all white and privileged; many women also came from different marginalized communities. This new wave also exposed the idea that people can be both oppressed and the oppressor, such as can occur among white women and black men, among others. Some even label the third wave as anti-feminism (Lotz, 2003). One of the primary theories that evolved from the third wave of feminism was intersectionality.

\subsection{Intersectional Theory}

In 1991, Kimberle Crenshaw wrote a journal article entitled Mapping the Margins: Intersectionality, Identity Politics, and Violence Against Women of Color. In this article, Crenshaw noted that "identity politics" can be important to many different groups of people including people of color and the LGBTQ community. Crenshaw stated, "For all these groups, identity-based politics has been a source of strength, community and intellectual development" (Crenshaw, 1991, p. 1242). Categorizing people was previously seen as biased while feminists and antiracists clashed over their need for dominance in the mainstream media. Both groups attempted to politicize their issues without understanding that all of these identities intersect. Crenshaw believed, "Ignoring difference within groups contributes to tension among groups" (Crenshaw, 1991, p. 1242). Crenshaw used the issue of violence against women as a way to acknowledge the intersecting identities of women of color and how they can be marginalized by both feminists and antiracists.

Crenshaw, a legal professor and scholar, first used her theory of intersectionality in 1989 to discuss several legal discrimination claims brought by black women against different national corporations. In all cases, the courts determined that these women could not be discriminated against because they were both black and women. They could only use one identity or the other to determine their type of discrimination. Crenshaw used the example of driving through an intersection to convey that a black woman can be harmed by several different cars, or forms of discrimination. Some of these forms of discrimination are similar for white women or for black men, but they are also different for both of these populations, as well (Crenshaw, 1989). Crenshaw goes on to articulate that traditional feminist theory has harmed black women because white women were typically speaking for all women, "Consequently," according to Crenshaw, "feminist theory remains white, and it's potential to broaden and deepen its analysis by addressing non-privileged women remains unrealized" (Crenshaw, 1989, p. 154). The second wave of feminism was based on the patriarchal experience of white women which meant that black women had to choose which category they wanted to identify with, either as women or as belonging to the black community. Crenshaw stressed that discourse was needed in order to respect the intersectional experiences of black women (Crenshaw, 1989).

Intersectionality has also been an important topic in LGBTQ research. Until recently, the mainstream LGBTQ groups have been dominated by white and privileged gay men and women. Activists gain momentum and media attention due to their common identity, despite the multidimensional needs of LGBTQ people of color and lower resource populations. People that identify as LGBTQ also have various intersections or identities, which means they can also face multiple forms of marginalization (Leachman, 2016).

\subsection{Integration of Queer Theory}

Queer theory rejects the traditional categories of gender and sexuality and includes the concept that heteronormativity is socially constructed. This theory dismisses the belief that everything other than heterosexuality is deviant and proclaims that the definition of gender is outdated and alienating (Chevrette, 2013). Bringing queer theory into the feminist discussion allows for a more intersectional discussion on deviance and difference. Class, race, ability and gender also cannot be assumed. While each person's experience can be similar, they can also be different. It is critical for child welfare professionals to understand these similarities and differences if they are going to be able to serve the LGBTQ foster youth population effectively. 


\section{Synthesis of Theory and Research}

Intersectional feminist theory may help explain the overrepresentation of LGBTQ youth in foster care. There are many reasons that these children end up in foster care more than non-LGBTQ youth, and once in foster care, why they are more likely to run away and to engage in risky behaviors. Intersectional theory can provide insight into understanding that these children often already experience more stress and trauma than other youth, particularly due to multiple marginalizations, and that this stress can affect the brain and body and cause more "acting out" behaviors. LGBTQ youth, just like the black women in Crenshaw's articles, may feel they have to choose one identity or one type of marginalization. They may have to ask themselves, "Am I black or gay or a woman?" rather than understanding that they can be all three because all of these identities intersect.

Most large-scale movements in the United States have been built upon essentialist attitudes, including LGBTQ activism. These larger movements often encourage action because they use the pre-existing values and ideals of the dominant activists. In order to challenge the essentialist patterns, each particular movement must conduct their own internal audit to understand why they are promoting this essentialist attitude. How does promoting essentialism help their cause? Historically, the organizations that have had the most intersectional attitudes have been made up of smaller, more grass-roots level activists, but they have rarely made the national changes with their essentialism that other, larger groups have achieved (Leachman, 2016).

Just like LGBTQ mainstream activists have used their essentialism to produce change in the public discourse, second wave feminists have also used "watered-down feminist theory" as a way to discredit the third wave, or intersectional forms of feminist theory (Lotz, 2003, p. 7). The language used in mainstream media is written for their audience, not for the revolutionizing activists that actually have a different perspective on mainstream culture. The third wave of feminism that includes intersectionality is not necessarily a criticism of the second wave. In fact, it could be viewed as an evolution from the second wave. All feminists can learn important new contributions to feminist thinking from women of color and anti-essentialist thinkers.

Just like feminists and LGBTQ activists, youth are also influenced by the mainstream media "essentialist" views and by their peers. The infamous double standard still reigns supreme in high schools. The traditional male sexual script perpetuates heterosexual boys being respected for having sexual experience, while the traditional female script perpetuates girls who are seen as sexually experienced as "sluts" who are then often bullied a result. Bullying and peer judgment is often significantly worse for LGBTQ youth, especially among those who do not conform to conventional gender roles. Feminist theory encourages the belief that bullying and negative peer attitudes are based on society's misogyny, which makes sense since research has validated this connection between bullying and sexual violence. These studies also suggest training and treatment groups introduced to these teenagers, which include feminist ideals and target gender bias, have been beneficial in preventing some types of sexual violence (Dunn, Clark \& Pearlman, 2017).

Feminist theory has also been influenced by society's views of masculinity and femininity. More recently, there have been additional perspectives on the definition of gender, but there are still only two main characterizations of masculine and feminine. First, the essentialist perception states that gender is fixed and based on our physical characteristics. The second perspective, based in social constructionist theory, states that ideas of gender are socially constructed and are not actually predicated on the physical body. Social constructionists state that gendered behavior represents the attempt to conform to society's norms (Everitt-Penhale \& Ratele, 2015).

Traditionally, masculinity in the United States has been intertwined with the hegemonic ideas of maleness, or a white, heterosexual man. Social constructionism allows for an understanding that there is no ideal masculine definition. The "perfect" masculinity changes from person-to-person and includes diverse principles based on race, gender, ethnicity and class (Everitt-Penhale \& Ratele, 2015). While the definition of hegemonic masculinity validates patriarchy and often the marginalization of women, the concept of masculinity itself is essentialist. Masculinity is based on the heteronormative ideal of gender. But, masculinity, just like femininity, is not fixed and there is no one, perfect image (Connell, 2005). Determining an ideal image of masculinity, it seems, is similar to the criticism waged against second wave feminism. That is, the idea is based on mainstream attitudes about what is beautiful and what is a man. That essentialist thought is the opposite of an intersectional point of view that would instead state that there are several different definitions of masculinity that include different identities and one is not better than the other, but the differences are important to note.

Studies suggest that children in foster care are often victims of multiple and ongoing traumas. This polyvictimization leads to a significantly higher risk for mental health issues throughout a child's life and into adulthood (Delaney, 2017). Children placed in foster care have frequently endured many different types of traumas prior to their removal. LGBTQ 
children are often placed in foster care due to their behavioral and mental health issues. Some parents declare they cannot handle their LGBTQ child's multiple behavioral problems and eventually the state must place them in foster care. Though they were not necessarily removed from their homes due to abuse, these LGBTQ children have most likely suffered several different types of abuse prior to their removal, providing a possible causal factor for their "acting out" behaviors (Sarri, Stoffrengen \& Ryan, 2016).

The concept of polyvictimization is not really a new phenomenon. Unfortunately, it appears to be the norm that a foster child will experience more than one type of maltreatment throughout their childhood. Polyvictims are much more likely to experience depression, substance abuse, and suicide attempts than their non-polyvictim peers. It also appears that sexual minority youth are significantly more likely to experience victimization than heterosexual youth (Sterzing, Ratliff, Gartner, McGeough \& Johnson, 2017, p. 2). LGBTQ children often experience many different types of trauma, even if they are not in foster care. Many live in an aggressive environment at home due to family members not accepting their identities. Peer rejection and all types of bullying are more common for LGBTQ children, as well (Sterzing et al., 2017).

\section{Discussion}

This section explores potential concepts and strategies that could be used to provide service providers with updated diversity training to assist them to better treat LGBTQ youth in foster care by 1) promoting a more intersectional feminist perspective when negotiating potential issues that could arise; 2) including an exploration of self-identity in these trainings, and 3) developing a better understanding of how heteronormative bias and perceptions of deviance can be perpetuated. Updated trainings could focus on intersectional identities including those associated with race, gender, class, ability and sexuality. One way to develop a greater understanding of intersectionality includes centering on personal identity. When service providers understand that a person has a subjective definition of their own life story, then it becomes easier to understand the many different identities they might experience. A new, more holistic discourse could help service providers, foster parents, and other stakeholders challenge the notion of heteronormativity and meet LGBTQ foster children and their parents where "they are," within their context, their reality. In sum, in order for child welfare professionals to provide the best service and treatment to LGBTQ children in foster care, they must have access to an exceptional diversity training program. An exceptional training program should include the incorporation of as many identities and intersections as possible in order to provide the most diverse and up-to-date information to the child welfare community.

In 1992, Rebecca Walker, a young student at Yale University, wrote an article in Ms. Magazine that famously stated, "I am not a postfeminism feminist. I am the Third Wave" (Walker,1992). Walker, the daughter of author and black feminist, Alice Walker, made a plea to all women to continue the fight, to continue to promote the powerful efforts towards empowerment. A large portion of the research on intersectionality and the third wave of feminism focuses on the essentialism of the mainstream activist groups. Many of these larger groups have made important strides within the patriarchy to empower women and give them a voice. However, the voice most often heard in these groups is the heteronormative, white, essentialist woman's voice. By focusing on oneness and color blindness, these women can often silence an important component of the feminist population. Intersectionality and third wave feminism allow for inclusivity while also celebrating differences and individual identity.

Feminist author Gloria Jean Watkins, known by her pen name as bell hooks, wrote about the need to change teaching styles in order to provide a more inclusive and real experience for students in her book, Teaching to Transgress. Though she wrote about the intersectionality pedagogy that is necessary in schools, this pedagogy could be used in any instructional environment, including in diversity training for child welfare professionals (hooks, 1994). As an educator at a liberal arts college, hooks was surprised to learn that her colleagues were hesitant to change their teaching styles and "unlearn racism" in order to be more inclusive. Just like these professors were challenged to "unlearn racism" (hooks, 1994, p. 38), child welfare professionals and other service providers can also be challenged through diversity training to unlearn their sometimes non-inclusive ways of thinking, including oppressive or marginalizing ways of thinking about racism, sexism, heterosexism, ableism, classism and other "isms."

Changing the way professors taught their students made some feel uncomfortable and worry about potential conflict in their classrooms. But, according to hooks, "No education is politically neutral" (hooks, 1994, p. 37). The practice of making students feel uncomfortable may be the best way to teach them about the important history of all of the "isms." Correspondingly, providing child welfare professionals with training to help them not to fear conflict when working with LGBTQ youth can be a positive step toward promoting greater inclusivity because it can provide a safe environment for helping students and clients learn about, understand, and respect individual voices (hooks, 1994, p. 
41). hooks also warned against the pitfalls of "tokenism" (hooks, 1994, p. 38). Accordingly, instead of relegating diversity training to the back end of an initial pre-service training, diversity should be its own, ongoing training throughout a child welfare professional's career. The authors suggest that LGBTQ training should be included as a separate, mandatory, and ongoing training, and that it should be viewed as an important component of other diversity and multicultural trainings.

Although intersectionality includes the acceptance and celebration of differences, all service providers in the child welfare field are united by a "shared commitment and a common good that binds us" (hooks, 1994, p. 40). All of the professionals, foster parents, and adoptive families want the same thing: to help children. If everyone is united by this ideal, then they are often "much more willing to face the challenge of multiculturalism" (hooks, 1994, 40).

One important way of teaching multiculturalism and diversity to others includes a discussion about self-identity. Some researchers use autoethnography to facilitate discussions about self-identity. According to Kaila Aida Story, autoethnography "allows for one's personal narrative and experiences to analyze culture and phenomenon critically through the praxis of connecting self-reflection to wider cultural, political and social prisms" (Story, 2015, p. 22). Black feminist theorists have used autoethnography as a way to understand their own experiences in each of the marginalized groups to which they belong.

Although autoethnography is primarily a tool used for qualitative research, the principles and premise can be used to teach intersectionality and multiculturalism to anyone. Using autoethnography allows a person to understand their own self-identity, and then they can see how their experiences relate to the social, political, and cultural beliefs in society. Use of this tool can cause some people to become angry when they confront the marginalization of their people. It can also allow others to forgive those that have marginalized them, which can help facilitate the healing process. By focusing on experiences that have affected their own identities and lives over time, they might also be able to understand the larger historical and cultural contexts and how marginalization has affected other people's identities and lives over time (Marx, Pennington \& Chang, 2017).

An important aspect of autoethnography and self-reflection includes understanding history. When training child welfare professionals on diversity and the current needs of LGBTQ youth in foster care, the "collective violent, homophobic past and present" (Young, 2015, p. 114) ought to be included. By learning the true history of various multicultural groups, service professionals can learn how far they have come, but also how far they still have to go to meet the LGBTQ population "where they are," from their context, their reality. History can help enhance the understanding of contemporary issues and stimulate action. Knowing the history and context of marginalized groups and reflecting on oneself within this history and context can encourage a new understanding of equality and social justice.

The logic behind, and rationale associated with, self-reflection has appeared recently in various marches across the country. People have marched for women, equality, and for gun control, among other causes. Not all have the same understanding regarding each of these issues, but each activist knows the issues are important, especially to particular groups. The LGTBQ community uses the term "ally" to describe these types of people. They may not be gay or transgender, but they support the rights and equity under the law that the LGBTQ community deserves.

As a logical transition to youth in foster care, it is especially important for service providers, including case managers, foster parents, Guardians ad Litem, and child welfare attorneys, to understand the diverse needs of LGBTQ children in foster care. Just like in the general population, not all LGBTQ children in foster care are alike. History validates that people and populations change over time. Therefore, providing ongoing LGBTQ cultural competency and diversity training is especially important for those who work with this diverse and ever-changing population.

An additional component of diversity trainings for child welfare professionals could include a discussion on heteronormativity. Such trainings could help dispel many of the myths associated with heteronormativity and deviant behavior. Queer theory, in conjunction with feminist theory and intersectionality, allows for an understanding that, "what we take as universal knowledge is biased" (Berkowitz, 2009, p. 118). This universal knowledge includes the belief that heterosexuality is always considered the norm. Heteronormativity can mandate ubiquitous definitions of masculinity and femininity that are not shared by everyone. Such definitions are often based on the principles of the dominant social group, or those in power, instead of including the multiple, intersecting identities of everyone else. Understanding the biases that are often associated with heteronormativity is critical to meeting those in the LGBTQ community "where they are" rather than from a heteronormative value and belief perspective.

Although marriage equality is now the law in the United States, LGBTQ individuals who choose to marry or have children are often still seen as "different" compared to heterosexual couples. This "heterosexual superiority," 
(Berkowitz, 2009, p. 124) can contribute to the stigmatization of an important part of the population. There is still a binary that exists in the media and society that states that people are either heterosexual or homosexual, gay or straight. Experiencing this binary can actually be a form of control by the dominant social group and, again, perpetuate stigmatization (Berkowitz, 2009). This stigmatization can lead to the bias among child welfare service providers that anything other than heterosexuality is deviant. Challenging the binary and heteronormativity can allow the marginalized to counter and redefine deviance. These new identities can help propel political and social change (Story, 2015).

Finally, understanding the reality of others requires learning about their culture, their history, their perceptions, their expectations, and their lived experiences. Diversity training that provides child welfare professionals with this critical information can help them to reduce any bias toward LGBTQ youth in foster care by getting "outside of themselves" and their own value and belief systems to better understand the reality of LGBTQ youth by meeting them "where they are" and not vice versa. This type of diversity training will also increase child welfare professionals' abilities to and advocate and intervene in the best interest of each LBGTQ child.

\section{Conclusion}

Despite the understanding that diversity training should be conducted among all child welfare professionals, research indicates that it is often the case that comprehensive diversity trainings, especially with regard to the needs of LGBTQ foster youth, are not being regularly and adequately implemented. As a result, the authors invite each state, city, municipality, and individual child welfare service provider to reflect on their ability to meet the needs of LGBTQ youth in foster care by meeting them "where they are," understanding that past, present, and ongoing trauma is a reality, and that focusing only on heteronormative values can often get in the way of promoting change that can incorporate intersectionality into strategic case plans. Essentialist values and beliefs drive the process of change, but the focus of the change specific to what is in the best interest of the LGBTQ child is what is most important.

Some of the information presented in this article is well known, highlighting the abundance of research on certain topics such as minority stress, stigma, masculinity and femininity, essentialism, and the overrepresentation of certain groups of children in the child welfare system, such as LGBTQ youth. LGBTQ children experience multiple stressors throughout their lives, including when they are removed from the only homes that they know because they are deemed unsafe. Child welfare workers are mandated to provide the necessary safety nets for children placed in foster homes or other out-of-home care, but this cannot happen adequately if the appropriate diversity training does not exist, especially for LGBTQ foster children. While it is understood that case managers and child welfare workers are diligent and committed in a system in which they are often overworked and underpaid, updating specific mandated diversity training with regard to LGBTQ foster youth is critical in order to effectively serve this population

If the status quo is to be changed, then the collective belief system must be changed as well. By mandating an intersectional diversity training program that includes an integral understanding of self and that challenges the biases associated with heteronormativity, then maybe the status quo can be changed. All children are different, all have different needs, and they must all must be protected.

\section{References}

Annie E. Casey Foundation. (2016). LGBTQ in Child Welfare A Systematic Review of the Literature. Retrieved from http://www.aecf.org/m/resourcedoc/aecf-LGBTQ2inChildWelfare-2016.pdf

Berkowitz, D. (2009). Theorizing Lesbian and Gay Parenting: Past, Present and Future Scholarship. Journal of Family Theory and Review, 1(3), 117-132. https://doi.org/10.1111/j.1756-2589.2009.00017.x

Castellanos, H. D. (2016). The Role of Institutional Placement, Family Conflict, and Homosexuality in Homelessness Pathways Among Latino LGBT Youth in New York City. Journal of Homosexuality, 63(5), 601-632. https://doi.org/10.1080/00918369.2015.1111108

Chevrette, R. (2013). Outing Heteronormativity in Interpersonal and Family Communication: Feminist Applications of Queer Theory "Beyond the Sexy Streets." Communication Theory, 23, 170-190. https://doi.org/10.1111/comt.12009

Child Welfare Information Gateway. (2016). Working with lesbian, gay, bisexual, transgender, and questioning (LGBTQ) families in foster care and adoption. Washington, DC: U.S. Department of Health and Human Services, Children's Bureau. 
Clawson, M. A. (2008). Looking for Feminism: Racial Dynamics and Generational Investments in the Second Wave. Feminist Studies, 34(3), 526-554.

Connell, R. M. (2005, December). Hegemonic Masculinity Rethinking the Concept. Gender and Society, 19(6), 829-859. https://doi.org/10.1177/0891243205278639

Courtney, M. E., \& Zinn, A. (2009, December). Predictors of Running Away From Out of Home Care. Children and Youth Services Review, 31(12), 1298-1306. https://doi.org/10.1016/j.childyouth.2009.06.003

Crenshaw, K. (1989). Demarginalizing the Intersection of Race and Sex: A Black Feminist Critique of Antidiscrimination Doctrine, Feminist Theory and Antiracist Politics. University of Chicago Legal Forum, 139-168.

Crenshaw, K. (1991). Mapping the Margins: Intersectionality, Identity Politics, and Violence Against Women of Color. Stanford Law Review, 43(6), 1241-1299. https://doi.org/10.2307/1229039

Crosland, K., Joseph, R., Slattery, L., Hodges, S., \& Dunlap, G. (2018, January). Why Youth Run: Assessing Run Function to Stabilize Foster Care Placement. Children and Youth Services Review, 85, 35-42. https://doi.org/10.1016/j.childyouth.2017.12.002

Delaney, A. X. (2017). Polyvictimization Experiences and Depression Among Youth Living in Foster Care. Criminal Justice Review, 42(2), 146-162. https://doi.org/10.1177/0734016817704699

Dubois-Comtois, K., Bernier, A., Tarabulsy, G. M., Cyr, C., St-Laurent, D., Lanctot, A.-S., St-Onge, J., Moss, E., \& Beliveau, M. J. (2015, October). Behavior problems of children in foster care: Associations with foster mothers' representations, commitment and the quality of mother-child interaction. Child Abuse and Neglect, 48, 119-130. https://doi.org/10.1016/j.chiabu.2015.06.009

Dunn MPH, H. K., Clark PhD, M. A., \& Pearlman PhD, D. N. (2017). The Relationship Between Sexual History, Bullying Victimization, and Poor Mental Health Outcomes Among Heterosexual and Sexual Minority High School Students: A Feminist Perspective. Journal of Interpersonal Violence, 32(22), 3497-3519. https://doi.org/10.1177/0886260515599658

Everitt-Penhale, B., \& Ratele, K. (2015). Rethinking 'Traditional Masculinity' as Constructed, Multiple, and Hegemonic Masculinity. South African Review of Sociology, 46(2), 4-22. https://doi.org/10.1080/21528586.2015.1025826

Eyal-Lubling, R., \& Krumer-Nevo, M. (2016, July). Feminist Social Work: Practice and Theory of Practice. Social Work, 61(3), 245-254. https://doi.org/10.1093/sw/sww026

Florida Department of Children and Families. (2018). Child Welfare Dashboards. Retrieved from http://www.dcf.state.fl.us/programs/childwelfare/dashboard/

Forkey MD, H., \& Szilagyi, M. P. (2014, October). Foster care and healing from complex childhood trauma. Child Maltreatment, The Pediatric Clinics of North America, 61(5), 1059-1072. https://doi.org/10.1016/j.pcl.2014.06.015

Funk, S., \& Funk, J. (2017, July). From a Pedagogy of Vulnerability to a Pedagogy of Resilience: A Case Study of the Youth and Gender in Media Project. Critical Questions in Education, 8(3), 297-321.

GLAAD. (2017, March 30). New GLAAD study reveals twenty percent of millennials identify as LGBTQ. Retrieved from https://www.glaad.org/blog/new-glaad-study-reveals-twenty-percent-millennials-identify- lgbtq

Goemans, A., van Geel, M., \& Vedder, P. (2015, April). Over three decades of longitudinal research on the development of foster children: A meta-analysis. Child Abuse and Neglect, 42, 121-134. https://doi.org/10.1016/j.chiabu.2015.02.003

Hague, R. (2016, May). Between the Waves: Currents in Contemporary Feminist Thought. Political Studies Review, 14(2), 199-209. https://doi.org/10.1111/1478-9302.12047

Hatch, T., Burwick, A., Gates, G., Baumgartner, S., \& Friend, D. (2014). Emerging Needs for Research on Human Services for Low-Income and At-Risk LGBT Populations. LGBTQ Policy Journal, 5, 3-10.

Hatzenbuehler, M. L., \& Pachankis, J. E. (2016). Stigma and Minority Stress as Social Determinants of Health Among Lesbian, Gay, Bisexual, and Transgender Youth: Research Evidence and Clinical Implications. Pediatric Clinics of North America, 63(6), 985-997. https://doi.org/10.1016/j.pcl.2016.07.003

Hooks, b. (1994). Teaching to transgress: Education as the practice of freedom. New York: Routledge. 
Human Rights Campaign. (2018). LGBTQ Youth in the Foster Care System. Retrieved from https://www.hrc.org/resources/lgbt-youth-in-the-foster-care-system

Irvine, PhD., A., \& Canfield, M.P.P., A. (2016, June). The Overrepresentation of Lesbian, Gay, Bisexual, Questioning, Gender Noncomforming and Transgender Youth Within the Child Welfare to Juvenile Justice Crossover Population. Journal of Gender, Social Policy and the Law, 24(2), 243-261.

Kerner, I. (2017). Relations of difference: Power and inequality in intersectional and postcolonial feminist theories. Current Sociology Review, 65(6), 846-886. https://doi.org/10.1177/0011392116665152

Lambda Legal. (2015). Getting Down to Basics. Tools to Support LGBTQ Youth in Care. Retrieved from https://www.lambdalegal.org/sites/default/files/publications/downloads/getting_down_to_basics_-_2015.pdf

Leachman, G. (2016, June). Institutionalizing Essentialism: Mechanisms of Intersectional Subordination Within the LGBT Movement. Wisconsin Law Review, 655-682.

Lee, E., Lee, Y., Kramer, C., \& Choi, M. J. (2017). Placement Stability of Children in Informal Kinship Care: Age, Poverty and Involvement in the Child Welfare System. Child Welfare, 95(2), 83-106.

Lin, C.-H. (2012, April). Children Who Run Away From Foster Care: Who Are the Children and What Are the Risk Factors? Children and Youth Services Review, 34(4), 807-813. https://doi.org/10.1016/j.childyouth.2012.01.009

Lloyd, M. H., Akin, B. A., \& Brook, J. (2017, June). Parental drug use and permanency for young children in foster care: A competing risks analysis of reunification, guardianship and adoption. Children and Youth Services Review, 77, 177-187. https://doi.org//10.1016/j.childyouth.2017.04.016

Lotz, A. (2003, March 22). Communicating Third Wave Feminism and New Social Movements: Challenges for the Next Century of Feminist Endeavor. Women and Language, XXVI(1), 2-9.

Maccio, E. M., \& Ferguson, K. M. (2016). Services to LGBTQ Runaway and Homeless Youth: Gaps and Recommendations. Children and Youth Services Review, 63, 47-57. https://doi.org/10.1016/j.childyouth.2016.02.008

Martin, M., Down, L., \&Erney, R. (2016). Out of the Shadows: Supporting LGBTQ youth in child welfare through cross-system collaboration. Washington, DC: Center for the Study of Social Policy.

Mark, S., Pennington, J. L., \& Change, H. (2017). Critical Autoethnography in Pursuit of Educational Equity: Introduction to the IJME Special Issue. International Journal of Multicultural Education, 19(1), 1-6. https://doi.org/10.18251/ijme.v19i1.1393

Prock, K. A. (2017, December). Federally Funded Transitional Living Programs and Services for LGBTQ-identified Homeless Youth: A Profile in Unmet Need. Children and Youth Services Review, 83, 17-24. https://doi.org/10.1016/j.childyouth.2017.10.023

Sarri, R., Stoffrengen, E., \& Ryan, J. P. (2016, August). Running Away from Child Welfare Placements: Justice System Entry Risk. Children and Youth Services Reveiw, 67, 191-197. https://doi.org/10.1016/j.childyouth.2016.06.012

Schuster, J. (2016). Intersectional expectations: Young feminists' perceived failure at dealing with differences and their retreat to individualism. Women's Studies International Forum, 58, 1-8. https://doi.org/10.1016/j.wsif.2016.04.007

Shaw, T. V., Bright, C. L., \& Sharpe, T. L. (2015, April). Child welfare outcomes for youth in care as a result of parental death or parental incarceration. Child Abuse and Neglect, 42, 112-120. https://doi.org/10.1016/j.chiabu.2015.01.002

Shpiegel, S., \& Ocasio, K. (2015, November). Functioning patterns among older adolescents in foster care: Results from a cluster analysis. Children and Youth Services Review, 58, 227-235. https://doi.org/10.1016/j.childyouth.2015.09.024

Snyder, R. C. (2008). What Is Third-Wave Feminism? A New Directions Essay. Signs, 34(1), 175-196. https://doi.org/10.1086/588436

Snyder, S. M., Hartinger-Saunders, R., Brezina, T., Beck, E., Wright, E. R., Forge, N., \& Bride, B. E. (2016, March). Homeless youth, strain, and justice system involvement: An application of general strain theory. Children and Youth Services Review, 62, 90-96. https://doi.org/10.1016/j.childyouth.2016.02.002

Spencer-Wood, S. (2016, September). Feminist Theorizing of Patriarchal Colonialism, Power Dynamics, and Social 
agency materialized in colonial institutions. International Journal of Historical Archaeology, 20(3), 477-491. https://doi.org/10.1007/s10761-016-0356-3

Sterzing, P. R., Ratliff, G. A., Gartner, R. E., McGeough, B. L., \& Johnson, K. C. (2017). Social Ecological Correlates of Polyvictimization Among a National Sample of Transgender, Genderqueer and Cisgender Sexual Minority Adolescents. Child Abuse and Neglect, 67, 1-12. https://doi.org/10.1016/j.chiabu.2017.02.017

Story, K. A. (2015). (Re)Presenting Shug Avery and Afrekete: The Search for a Black, Queer, and Feminist Pleasure Praxis. Black Scholar, 45(4), 22-35. https://doi.org/10.1080/00064246.2015.1080913

U.S. Department of Health and Human Services, Administration for Children and Families, Administration on Children, Youth and Families, Children's Bureau. (2011). Information Memorandum. Lesbian, Gay, Bisexual, Transgender and Questioning Youth in Foster Care, Retrieved from https://www.acf.hhs.gov/sites/default/files/cb/im1103.pdf

U.S. Department of Health and Human Services, Administration for Children and Families, Administration on Children, Youth and Families, Children's Bureau. (2018). Child Maltreatment 2016. Retrieved from https://www.acf.hhs.gov/cb/research-data-technology/statistics-research/child-maltreatment

U.S. Department of Health and Human Services, Administration for Children and Families, Administration on Children, Youth and Families, Children's Bureau. (2016). The AFCARS Report. Retrieved from https://www.acf.hhs.gov/sites/default/files/cb/afcarsreport24.pdf

U.S. Department of Health and Human Services, Administration for Children and Families, Administration on Children, Youth and Families, Children's Bureau. (2012). The Children's Bureau Legacy, Ensuring the Right to Childhood. Retrieved from http://cb100.acf.hhs.gov/CB_ebook

Walker, R. (1992, January). Becoming the Third Wave. Ms., 2(4), 39-41.

Ward, W. G. (2017). Coming Out and Leaving Home: A Policy and Research Agenda for LGBT Homeless Students. Educational Researcher, 46(9), 498-507. https://doi.org/10.3102/0013189X17733964

Williams Institute, UCLA School of Law. (2016). LGBT Data and Demographics. Retrieved from https://williamsinstitute.law.ucla.edu/visualization/lgbt-stats/?topic=LGBT\#density

Young, S. L. (2015). I Never Thought I'd Be an Advocate: Reflections on LGBT Activism and Engaged Feminist Scholarship. Women and Language, 38(1), 113-120. 